\title{
|Jak czytaliśmy teksty o uchodźcach Jarosława Mikołajewskiego? Refleksje nauczyciela po lekcji akademickiej
}

\author{
|Marcin Szopiński
II Liceum Ogólnokształcace
im. gen. Władysława Andersa w Chojnicach
}

Inspiracją do napisania tego artykułu była lekcja akademicka prof. Katarzyny Kuczyńskiej-Koschany przeprowadzona w II Liceum Ogólnokształcącym im. gen. Władysława Andersa w Chojnicach. Kolejny z wykładów w ramach współpracy szkoły z Uniwersytetem im. Adama Mickiewicza w Poznaniu dotyczył książek Jarosława Mikołajewskiego pt. Wielki przypływ (reportaż) i Żebrak (poezja).

\section{Szkoła a problemy współczesności}

Wśród wielu pytań w kontekście uchodźczym nasuwają się między innymi takie: Jak edukacja reaguje na problemy współczesnego świata? Czy tradycja polskiej szkoły jest przygotowana na stawianie pytań o uchodźców? Czy jest otwarta na to, co dzieje się we współczesnym świecie? A może jest tak, że w podstawie programowej pojawiają się zawsze te same zagadnienia i nie potrafimy wyjść poza dawno utrwalony zakres tematyczny?

Czyżby było tak, że podejmowanie tematyki związanej np. z uchodźcami, migracją (zarówno zarobkową jak i polityczną), terroryzmem, nacjonalizmem itd. zależy od odwagi nauczyciela, od jego chęci, potrzeby uświadamiania dzieci i młodzieży, od interpretacji przez pryzmat doświadczeń współczesności, niezależnie od niezmiennych od lat lektur? Właśnie dlatego tak potrzebne są spotkania uczniów z wykładowcami uniwersyteckimi. Dzięki nim uczniowie mają możliwość ucieczki od szkolnego schematu, a jednocześnie poznają smak uniwersyteckiego dyskursu. Doświadczają zupełnie innego spojrzenia na literaturę, która bez wątpienia odpowiada na wiele pytań współczesnego człowieka. Konieczne jest przybliżanie uczniom literatury spoza kanonu lektur szkolnych, do omówienia których zobligowany jest nauczyciel, a wykładowca uniwersytecki 
może wykorzystać kompetencje uczniów do interpretacji zagadnień pomijanych w programach nauczania.

\section{Interpretacja akademicka, historycznoliteracka a interpretacje uczniowskie}

Pozwolę sobie w tym miejscu na przedstawienie najważniejszych aspektów wykładu, w którym brali udział moi uczniowie.

Rozmawiać o uchodźcach, to rozmawiać o historii ludzkości. Gatunek ludzki przecież nieustannie migruje. W poszukiwaniu lepszego łowiska, łagodniejszego klimatu, spokojniejszych sąsiadów czy wreszcie nowego, cudownego miejsca, które będzie substytutem raju. Od takich spostrzeżeń rozpoczęła się lekcja akademicka. Kolejne wnioski rozwijały pierwszą myśl. My, Polacy, również jesteśmy uchodźcami. W naszej tradycji bardzo głęboko zakorzenił się np. mit Wielkiej Emigracji. Tam powstały dzieła polskiego romantyzmu, bez których trudno sobie wyobrazić historię literatury polskiej. A fale polskich emigrantów nadal płyną na Zachód.

Jeżeli więc sami emigrujemy, to dlaczego każdy przybysz jest traktowany przez naszych rodaków jako potencjalny najeźdźca? Czy będąc potomkami emigrantów - zarówno zarobkowych, jak i politycznych - mamy moralne prawo powiedzieć komukolwiek „nie”? Od takich pytań łatwo przejść do przykładów ze współczesnej literatury, nie tylko polskiej. Przywołanie utworów Hotel Ukraina Bohdana Zadury, Zapiski z Homs Jonathana Littella czy Wolfganga Bauera Przez morze. Z Syryjczykami do Europy zakreśliło spektrum najważniejszych problemów, które podejmuje literatura opisująca najbliższą nam rzeczywistość.

Najwięcej miejsca poświęcono reportażowi Jarosława Mikołajewskiego pt. Wielki przypływ, który jest wzruszającą relacją, świadectwem humanizmu mieszkańców Lampedusy. To oni z dnia na dzień stali się cichymi bohaterami. Ogrom katastrofy humanitarnej, która wynika z niekontrolowanej w żaden sposób fali przypływu uchodźców, zaskoczył cały świat, ale tylko mieszkańcy tej małej wyspy znaleźli się w centrum tragedii. Poruszające relacje autora reportażu mówią prawdę o współczesnym świecie, w którym obok strachu i bezsilności obecny jest niespotykany heroizm, np. burmistrz Lampedusy Giusi Nocolini, odznaczonej w 2016 roku przez „Tygodnik Powszechny” Medalem św. Jerzego za walkę ze „smokiem” obojętności i uprzedzeń; świecie, w którym lekarz, ksiądz, zwyczajni mieszkańcy dają świadectwo humanizmu przywracającego wiarę w dobro.

Wnioski wynikające z lekcji (zarówno z wykładu, jak i z rozmów) to potrzeba świadomości sytuacji, w której znajduje się obecnie Europa, ale też świadomość przeszłości i polskich doświadczeń z emigracją. Z toku lekcji najważniejszą stała się konstatacja, że konieczna jest nasza pomoc uchodźcom, świadomość ich tragicznej egzystencji i postawa bezsprzecznie humanistyczna. Taką optykę prezentowała większość uczniów, ale byli również 
tacy, dla których każdy obcokrajowiec, a szczególnie innego wyznania, stanowi zagrożenie. Prezentowane teksty odnosiły się głównie do uchodźców z terenów Afryki północnej, ale na wspomnienie o możliwej fali uchodźców ze Wschodu pojawiły się podobne głosy sprzeciwu. Poglądy te są widoczne w części ankietowej, którą chciałbym omówić poniżej.

\section{Uczniowskie odwołania do literatury i do własnych doświadczeń.}

Na początku września, po kilku miesiącach, które minęły od lekcji akademickiej w II LO, poprosiłem uczniów III klasy humanistycznej, obecnych w większości na wiosennym wykładzie, by odpowiedzieli na dwa pytania oraz podzielili się własnymi refleksjami na temat wiersza J. Mikołajewskiego pt. Tak też się śniło. Ankieta miała sprawdzić, jak uczniowie po kilku miesiącach postrzegają omawiany problem. Czy zmieniło się ich zdanie na temat uchodźców, czy pod wpływem wydarzeń minionych miesięcy (kolejne zamachy terrorystyczne, burzliwe dyskusje, często jednostronne przekazy medialne) zaszły jakieś zmiany w ich spojrzeniu.

Warto przytoczyć wybrane opinie i najciekawsze sformułowania interpretacyjne.

1. Odwołaj się do swoich przemyśleń po lekcji o uchodźcach. Opisz je i jeżeli w jakikolwiek sposób zmieniło się twoje spojrzenie na to zagadnienie, napisz.

- Jestem za przyjmowaniem uchodźców. Ucieszyłam się, że istnieją osoby, które aktywnie pomagają i poszerzają grono popierających.

- Moje zdanie na temat uchodźców było i pozostało bardzo podobne do zdania p. Profesor [zgoda na przyjmowanie uchodźców i pomoc humanitarną - M. Sz.], jednak myślę, że mogło się zmienić myślenie osób o innych poglądach.

- Pierwszy raz miałam szansę wysłuchać poglądów i opinii, z którymi w pełni się zgadzam. Przed wykładem nie miałam aż tak szerokiej wiedzy na temat uchodźców i problemów, z którymi się zmagają, ale byłam świadoma, że działania niektórych krajów, w tym Polski, są absolutnie nieprawidłowe w kwestii imigracji.

- Lekcja o uchodźcach zmusiła mnie do refleksji nad życiem. Próbowałam uświadomić sobie co przeżywają osoby, które decydują się na niebezpieczną przeprawę do lepszego życia. Zmieniłam swoje myślenie na temat uchodźców.

- Po lekcji przeprowadzonej przez Panią Profesor zmieniło się moje nastawienie do uchodźców. Moje negatywne podejście wykreowane przez media, zmieniło się. Zaczęłam zastanawiać się, co zrobiłabym na miejscu tych ludzi.

- Moje wrażenia po lekcji o uchodźcach były zdecydowanie pozytywne. Rzeczowe, pełne empatii i zwykłej ludzkiej życzliwości 
argumenty za przyjmowaniem uchodźców i pomocą im, stanowiły odświeżającą odmianę od coraz popularniejszych, niczym nie popartych, ksenofobicznych przekonań.

- Dobrze, że była u nas taka lekcja. Powinno się o tym rozmawiać jeszcze częściej.

- Również dzisiaj moja odpowiedźnie byłabyjednoznaczna. Argumenty „za” [przyjmowanie uchodźców - M. Sz.] przedstawione podczas wykładu, są jak najbardziej trafne. Natomiast nie jestem pewna, czy ojczyste bezpieczeństwo nie jest sprawą pierwszorzędną.

- Po lekcji o uchodźcach miałam poczucie rozdarcia. Z jednej strony bardzo bym chciała pomóc osobom z krajów ogarniętych wojną (...), ale czuję strach (...) strach o rodzinę, przyjaciół i Polskę. Część uchodźców jest sprowadzana nie po to, żeby im pomóc, ale po to, żeby Europa upadła. Nieprzyjacielem Europy nie są uchodźcy, ale wysłannicy tzw. państwa ISIS, którzy pod postacią uchodźcy dostają się do Europy.

- Uważam, że trzeba im pomóc, ale rozumiem także, dlaczego ludzie nie chcą ich przyjąć do kraju. Strach nie jest dobrym doradcą, ale jest zaskakująco skuteczny.

- Przeprowadzona lekcja utwierdziła mnie w przekonaniu, że uchodźcy to również ludzie i nie możemy być wobec nich obojętni. (...) rozumiem skąd bierze się obawa przed uchodźcami i uważam, że każdy sam ma prawo podjąć decyzję, czy chce kogoś przyjąć pod swój dach.

- Z Jednej strony powinniśmy być solidarni (...). Z drugiej zaś mamy wiele przykładów na to, jak wygląda podziękowanie za pomoc (...). Rozboje, zamieszki, działania przeciwko religii chrześcijańskiej. (...) Nie potrafię jasno określić swojego zdania na ten temat.

- Uważam, że uciekać z kraju powinni tylko ci, którzy naprawdę potrzebują pomocy i tylko tam, gdzie panuje taka sama religia.

- Raczej nie zmieniło się moje myślenie o uchodźcach. Gdy jakiś kraj przyjął ich do siebie, to zwiększyła się liczba zamachów.

- Mojemu poglądowi towarzyszy strach, patrząc na to, co się dzieje wokół (w krajach, w których okazano im dobroć, pomoc) zamachy terrorystyczne, liczne gwałty i napady.

- Mikołajewski ma konkretne poglądy na temat uchodźców. Są one dla wielu kontrowersyjne, ponieważ wielu Polaków jest przeciwko uchodźcom. Sama też nie zgodziłam się z kilkoma sprawami. Moje poglądy po tej lekcji się nie zmieniły i nadal się ich trzymam.

- Dalej towarzyszy mi strach, jak patrzę, co się dzieje wokół naszego kraju i na to, co może się stać, gdy ich wpuścimy do Polski. Może nie każdy muzułmanin to terrorysta, ale każdy terrorysta to muzułmanin. 
- Moje myślenie nie zmieniło się, tym bardziej że widać i słychać, co się dzieje w krajach, w których decyzje o przyjęciu ich były pozytywne. Ciągłe zamachy, strach. Owszem, są tacy, którzy naprawdę potrzebują wsparcia, ale co, jeśli większość z nich organizuje zamachy na innych ludzi. Jeśli nasz kraj miałby przyjąć uchodźców, powinien znaleźć dla nich odizolowane miejsce, skąd nie mieliby wyjścia. W takiej sytuacji pomoglibyśmy im, nie narażając swojego własnego życia.

\section{Wnioski:}

Opinie uczniów są bardzo różne. Wielu podziela pogląd, że w polityce państwa powinno się znaleźć miejsce na prawdziwą debatę o uchodźcach i należy im pomagać. Istotne jest również to, że nikt nachalnie uczestników wykładu nie zmuszał do podzielenia tych poglądów, a jedynie przez wielość przykładów prof. Kuczyńska-Koschany wskazywała na kierunek działania $\mathrm{w}$ tej kwestii, z czego wyłoniła się jasna teza, że bezsprzecznie należy pomagać drugiemu człowiekowi.

Uczniowie mają również świadomość niebezpieczeństw istniejących we współczesnym świecie. I wielu z nich chciałoby pomóc, ale obawa o własne niebezpieczeństwo hamuje ich działania. Pojawiają się również stanowcze wypowiedzi, w których sprzeciwiają się jakiejkolwiek pomocy uchodźcom. A jeżeli już to robić, to stworzyć swoiste getto, które wykluczy możliwość asymilacji. Wszystko dlatego, że do Polski wśród uchodźców mogą przybyć terroryści z ISIS.

Drugie pytanie odwoływało się do osobistych doświadczeń uczniów. Zostało tak sformułowane, by zasugerować inny problem - ekonomiczny a nie polityczny, a tym bardziej religijny.

2. Czy spotkałeś się z sytuacją, że ktoś z twoich znajomych, przyjaciół, z najbliższej rodziny, musiał wyjechać na Zachód w celach zarobkowych, politycznych lub innych? Jeżeli tak, opisz krótko swoje przemyślenia z tym związane.

- Kuzynostwo osiedliło się za granicą w celach zarobkowych.

- Wiele osób w moim otoczeniu wyjeżdża zarabiać na Zachód i jest to traktowane powszechnie jako coś normalnego i racjonalnego.

- W mojej rodzinie są osoby, które od kilkunastu lat mieszkają oraz pracują za granicą. Osoby, które uczciwie chcą prowadzić swoje życie poza granicami swojej ojczyzny, zasługują na jak najlepsze warunki i równe traktowanie bez względu na ich oryginalne pochodzenie.

- Mój ojciec chrzestny kilkanaście lat temu wyjechał do Niemiec w celu zarobkowym, zabierając ze sobą całą swoją rodzinę. Bardzo 
podniósł się jego standard życia, (...) nie myśli nawet o powrocie do ojczyzny.

- Moim osobistym doświadczeniem jest wyjazd wujka (ojca trojga dzieci), wyjechał do pracy w Niemczech z powodu niskiego zarobku w kraju. Po wprowadzeniu ustawy 500+ wrócił do Polski, bo dla niego rodzina jest ważniejsza od wysokich zarobków za granicą. Teraz pracuje w Polsce.

- Większość mojej rodziny wyjechała do Niemiec, a znajomi do Wielkiej Brytanii. Dobrze im się powodzi. Spotkałam mężczyznę, Polaka, który jeździł tirem tylko i wyłącznie w celach zarobkowych, po Islandii. Był „pisowcem”. Nie była to zbyt przyjemna rozmowa. Temat uchodźców i polityki był poruszany nieustannie.

- Większa część mojej rodziny wyjeżdża na zachód w celach zarobkowych. Nie mam żadnych negatywnych doświadczeń dotyczących tych zdarzeń. Moja rodzina wyjeżdża, by zapewnić godne życie sobie i najbliższym.

- Tak, lecz nie można porównywać tego do masowej emigracji ludzi, których tożsamości nie można skontrolować.

- Byłam w pracy w Szkocji. (...) Mogę odnieść się do mojego kuzyna, który niecały miesiąc temu był na wakacjach w Hiszpanii. Gdyby odleciał z lotniska pół godziny później, już by go prawdopodobnie nie było, a tak uniknął zamachu. Widać więc wyraźnie, że tam, gdzie są muzułmanie, zazwyczaj są zamachy, nie zawsze, ale są.

- Wyjazd za granicę wiąże się z pozostawieniem dotychczasowego życia. Jest trudną decyzją.

- Praca zarobkowa za granicą któregoś z rodziców nie ma dobrego wpływu na relacje $\mathrm{w}$ rodzinie (...), są pieniądze, ale nie ma miłości. Zdaję sobie jednak sprawę z faktu, że to pytanie ma na celu uświadomienie nam, że Polacy też są emigrantami ekonomicznymi. Koleżanka wyjechała do Londynu (...), pełno żołnierzy z karabinami strzegło porządku. Nie chciałabym, żeby było tak w naszym kraju.

- Mój tata i brat pracowali na Zachodzie. Myślę, że nie doznali żadnych przykrości ze strony tamtejszych mieszkańców. Jednak sama świadomość, że są daleko od domu wśród tak naprawdę zupełnie obcych ludzi, powodowała, że nie czuli się tam dobrze. Niestety muszę przyznać, że sami byli wrogo do nich nastawieni. Nie liczyło się dla nich, że tak naprawdę to oni są tymi „obcymi”.

\section{Wnioski:}

Uczniowie udzielali zaskakujących odpowiedzi. Można je uogólnić następująco: emigracja zarobkowa jest rzeczą normalną i w związku z tym, że Polacy często zarabiają w kraju tak mało, że nie są w stanie utrzymać rodziny, albo tracą pracę nie ze swojej winy, wszelkie przywileje $\mathrm{z}$ bycia 
Europejczykiem po prostu im się należą. Czasami zachowują się na Zachodzie jak u siebie i rodowitych mieszkańców mają za „obcych”, a zarabiane pieniądze przesyłają do kraju. Wszystko odbywa się zgodnie z prawem i tylko czasami żal rodzinnych więzi.

Nie pojawiły się w wypowiedziach skojarzenia, które by wskazywały na choćby odległe analogie czasów współczesnych z przeszłością, historią Polaków, kiedy sami stawali się emigrantami. Teraźniejszość najwyraźniej została uznana przez uczniów za naturalny stan rzeczy, normalność w zjednoczonej Europie.

Ostatnie zadanie dotyczyło wiersza Jarosława Mikołajewskiego, do którego prof. Kuczyńska-Koschany odwoływała się w czasie wykładu.

3. Przedstaw swoje refleksje na temat wiersza J. Mikołajewskiego Tak te $\dot{z}$ się śniło [z tomu: Żebrak]

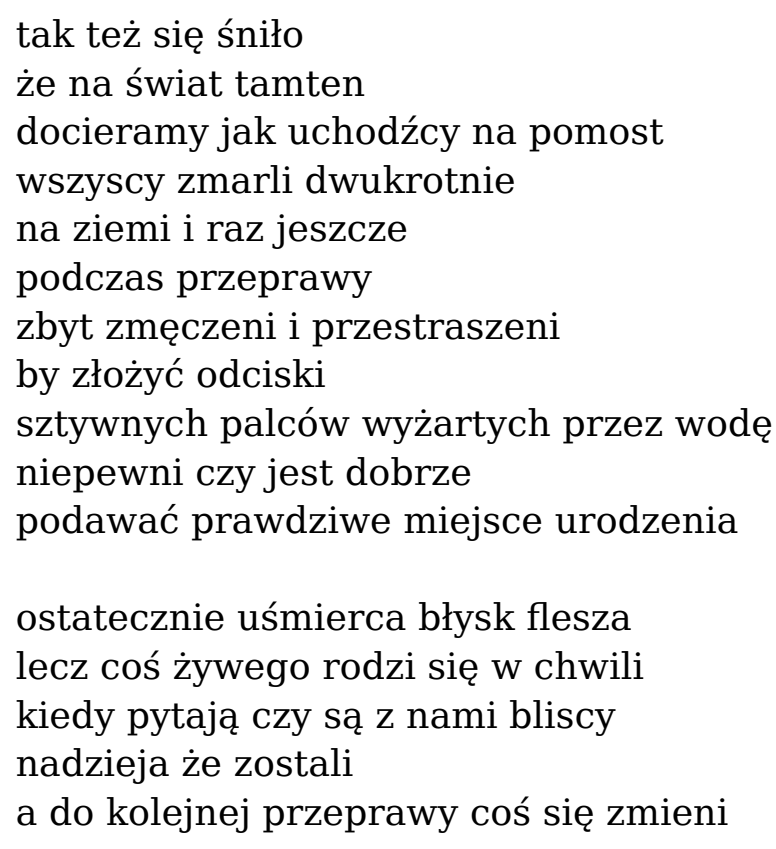

Poniższe wypowiedzi nie są pogłębioną interpretacją, a tym bardziej próbą kontekstowej analizy utworu. Stanowią swoistą refleksję na omawiany temat i mogą być traktowane jako uzupełnienie dwóch poprzednich pytań.

- Polacy od ponad 150 lat emigrują, a są obojętni na losy ludzi, którzy w obecnej chwili nie mają miejsca na świecie. Niestety, hipokryzja jest mocno zakorzeniona w każdym $\mathrm{z}$ nas.

- Autor porównuje drogę człowieka do zbawienia, do podróży ludzi na inny kontynent w celu lepszego życia. Wiersz pokazuje, że każdy człowiek i tak w końcu stanie się uchodźcą.

- Ludzie boją się o siebie podczas drastycznych i przymusowych zmian otoczenia, nie są niczego pewni. Boją się podawać swoje dane i informacje na swój temat. Jednak kiedy w grę wchodzi rodzina, wszystko się zmienia i chcemy dobra bliskich za wszelką cenę. 
- Wiersz obrazuje nasze osobiste obawy, niepewności, porównując je do przepraw i ucieczek przepełnionych strachem uchodźców.

- Czas przeszły użyty w drugiej zwrotce jest celowy. Tak, jakby ludzie, którzy imigrują, przestali być ludźmi (...) ponieważ większość społeczeństwa traktuje ich jak bydło, terrorystów, osoby, które kradną pracę.

- Zarówno dusze jak i uchodźcy boją się przyznawać do swojej tożsamości „za życia”, w obawie o konsekwencje mogące wynikać chociażby z grzechów narodu, którego są częścią.

- Uchodźcy ukazani w wierszu przypominają żebraków, którzy walczą o swój kawałek ziemi, o miejsce na świecie. Nieustannie żyjący nadzieją, że coś się zmieni.

- Może powinniśmy też zastanowić się nad tym, jak by było, gdyby nas spotkał taki los. Ten tekst nakłania do wielu refleksji.

- Mikołajewski zwraca uwagę na media, które zarządzają strachem i manipulują ludzi do rasistowskich zachowań i nienawiści wobec drugiego człowieka.

- Wiersz ten skłania nas do zastanowienia się, co czują ludzie, którzy są tacy jak my, a jednak są potępiani tylko dlatego, że zostają zmuszeni do opuszczenia swojego kraju i skazani na cudzą łaskę.

- Błysk flesza może oznaczać Boga.

- Jest to nowe życie, „życie po życiu”, które zostało jednak okupione cierpieniem i strachem.

\section{Wnioski:}

Przemyślenia interpretacyjne wskazują dużą wrażliwość młodzieży, a odczytanie wiersza przybiera $\mathrm{w}$ wielu przypadkach wymiar egzystencjalny. Uczniowie współczują i współodczuwają, wskazują na cierpienie uchodźców i utożsamiają się z nim, widzą okropieństwo losu. Spostrzegają, że cierpienie może mieć wiele znaczeń. I jeżeli w swoich wcześniejszych wypowiedziach niektórzy stanowczo wypowiadali się przeciwko uchodźcom, teraz takich głosów nie ma. Czy można w takim razie wnioskować, że los obcych jest im raczej obojętny wtedy, gdy ma bezpośrednie przełożenie na ich codzienność, a jedynie abstrakcyjny uchodźca skłania do współczucia?

\section{Problem Innego}

Problem Innego istnieje $\mathrm{w}$ lekturach szkolnych raczej marginalnie. Jeżeli już się pojawia, to w ujęciu na tyle abstrakcyjnym, że współczesnych uczniów nie dotyczy (choćby pozytywistyczne pojęcie asymilacji Żydów poruszane przy okazji interpretacji noweli Marii Konopnickiej Mendel Gdański). Współczesne ujęcie problemu w szkolnej świadomości nie istnieje. Owa „obcość” rozpatrywana jest tylko z perspektywy Polaka 
- emigranta, którego świat nie rozumie, ale uczeń w pełni się z nim utożsamia i interpretuje ją zgodnie z duchem XIX-wiecznej martyrologii. Dlatego tak ważne jest przywoływanie współczesnych utworów literackich, umieszczanie ich w kontekście XIX i XX wieku i prezentowanie paraleli między nimi a uchodźcami XXI wieku. Równie ważne jest, by głos taki wybrzmiewał z perspektywy katedry uniwersyteckiej, co bezsprzecznie wzmacnia jego przesłanie. Lekcje uniwersyteckie w szkołach średnich stają się więc głosem współczesnego humanizmu i sprawiają, że licealiści patrzą na otaczającą ich rzeczywistość w znacznie szerszej perspektywie.

Wydaje się, że środowisko nauczycielskie rozumie, że najważniejszym bogactwem edukacji jest absolwent, który w swoim dorosłym życiu potrafi krytycznie patrzeć na świat, dostrzegać innych, pomagać i akceptować. Pomimo wielu niepokojów o współczesną edukację wierzę, że dzięki pracy nauczycieli, ich odwadze $\mathrm{w}$ stawianiu wychowankom trudnych pytań, ukształtują świadomych obywateli. Bo przecież każdą reformę zamieni następna, a edukacja trwa. Sztuką jest przecież interpretacja rzeczywistości, w której żyjemy! 
